\title{
We were invited to friendships
}

\author{
Lived hospitality
}

DOI: https://doi.org/10.30664/ar.92002

(c) Attribution 4.0 International (CC BY 4.0)

$\mathrm{T}$ his article explores hospitality in relation to migration within the framework of spatial theory and calling. The material of the article is based on fieldwork carried out in the Nordic borderlands and conducted in relation to a research project exploring Nordic hospitality. The concept and context of the borderland, as well as the methodological development of this project, are based on spatial theory, phenomenology and theology. The material discussed are excerpts from a small fieldwork narrative about borderland experiences, and interviews regarding events that took place on the Russian-Norwegian border during the so-called refugee crisis in 2015-16. The article aims at, by means of these narrative excerpts, exploring how conceptualisations of hospitality, by discussing them in relation to the concept of calling from Scandinavian creation theology, may contribute to extensions of both concepts.

\section{Introduction}

The article explores the conceptualizations of the notion of hospitality, based on short excerpts of fieldnotes from fieldwork carried out in North Norway in 2017-18. The cited field narrative and interviews regard understandings and experiences of hospitality in the region as a borderland, meaning here an area in close vicinity to international borders, actualized by the so-called refugee crisis of 2015-16. The article relates to work exploring decolonial research strategies (cf. Lid and Wyller forthcoming), concerning what voices, bodies and practices make up the critical counter-power, and where it is rooted. Such strategies are characterized by collaborations focused on subject-to-subject relationships between the researcher subject and research field, including the space in which the research takes place. The article is not aimed at doing empirical analysis of data to make certain truth claims concerning migration issues. Rather, the aim is to use excerpts from two of the respondents' short narratives, the researcher subject's experience, and reflections on the local migration crisis, as well as the events' cultural and historical context, to discuss conceptualizations of hospitality. The discussion takes place within the framework of spatial theory primarily in the tradition of the French sociologist Henri Lefebvre (2003 [1970], 2007 [1974], 2008 [1961]), and calling in the tradition of Scandinavian creation theology, linking this to embodied spatial calling. Furthermore, the spatial theory relates both to the emphasis on the lived encounters in the research strategy, as well as the theoretical framework.

\section{Space and hospitality}

The very short introductory version of Lefebvre's theory of the production of space 
(2007 [1974]) in this context is that space is to be understood in an active sense as an intricate web of relationships that is continuously produced and reproduced. Spaces are formative. This spatial analysis thus concerns active processes of social production. In the context of [Nordic] borderlands, then, both the dis-placed and the 'placed' are all producing space, and that space exists from the moment of social encounter.

The interpretations of space are connected to the relationships between three different analytical levels - the perceived, the conceived and the lived - and how changes occur in the interplay between all the levels of space. A space is constantly in motion, always different, always being moved forward - the world is moved forward by contrasts, contradictions and tensions (Lefebvre 2007: 42). Space is to be understood less as something that is, but as something we do, or in the interpretation of Kirsten Simonsen, space is a verb rather than a noun (Simonsen 2010: 45).

This is where I am concerned with hospitality; this is my starting point: in the spaces that occur when humans encounter each other. Furthermore, when I discuss hospitality it is not in church or politics, but in spaces of civil society, where people are, where life is lived, and where they interpret and understand hospitality. I always start in the lived, in the embodied, as humans are situated bodies. Whilst, furthermore, understanding them not only as situated, but also as a situation, the meaning of the body opens up in the process of creating meaning (Nahnfeldt 2016: 66).

So, let us start with a quote: 'The number of unauthorized migrants who have died attempting to cross the borders to Europe is transhistorical and has reached frightening heights' (Chattopadhyay 2019: 157).

This quote is citing an article written in
2009 (van Houtum and Boedeltje 2009). We all know that following the events of 2015 this quote is outdated, and with the current situation in Greece and Turkey, including now the impact of the COVID19 virus, we may be standing at the threshold of yet another transhistorical number of deaths on our shores and along our borders, as 'sovereign states claim monopoly control over the mobility of people' (Chattopadhyay 2019: 150).

Every day the news is filled with human tragedy at or near borders. There is, perhaps not surprisingly, rather little of any counter-narratives; the human encounters, openings and possibilities that also make up life at the borders. 'B/ordering separates but also brings together. Respectively, borders are open to contestations at the level of the state and everyday life' (Chattopadhyay 2019: 151).

\section{Border encounters}

The material of the article is based on fieldwork from the Nordic borderlands, conducted in relation to a research project exploring Nordic hospitality. ${ }^{1}$ The concept and context of the borderland, as well as the methodological development of the project is based on spatial theory, phenomenology and theology.

Border situations need to be emphasised as 'radical stages of relations' (Agier 2016: 23). The shift of the borders to becoming a relational arena has significance for how we approach the migrant as a concrete and embodied human being, rather than homo sacer, a mere biological fact (Agamben 1998), 'abandoned to the

1 'NORDHOST: Nordic Hospitalities in the Context of Migration and Refugee Crisis', a project financed by the UiO: Nordic, one of the University of Oslo's interdisciplinary strategic research areas. 
unconditional power of the sovereign' (Katz 2017: 2). This is explored through bottom-up insights developed for events in the Nordic borderlands.

The empirical, 'from below' and enacted and lived encounters belong to post-colonial traditions, challenging and reconfiguring migration binaries such as guest/ host; victim/agent; villain/victim, etc. (cf. Machado et al. 2018).

I aim at showing and discussing how hospitality may take the concept of calling from Scandinavian creation theology, and become an interesting and fruitful extension of both concepts.

Traditional notions of both hospitality and the concept of calling may become passive, as binaries such as guest and host are traditionally seen as pre-determined and set. I aim to argue that hospitality may be pinpointed as a pre-reflexive action, thus challenging the possible rigidity of the roles and their binary aspect.

In Lutheran theology 'calling' is the name for the task, God-given to humans, of taking responsibility for each other. The responsibility is founded on an idea about humans' co-creating missions and adds a sacred dimension and ethical value to interpersonal encounters and practices (Nahnfeldt 2016). Cecilia Nahnfeldt points out that openness to calling entails being prepared for disruption in the calling. She who is attentive to her fellow human does not decide the time and space for the callings. It is about letting oneself be interrupted, and to bear seeing or daring to receive an opening ( $i b i d$.).

The calling thus bears the characteristic of disruption or an encounter; it also takes place in the minor encounters in lived spaces, such as the fleeting encounter between a beggar and a passer-by in a public transport station (Rønsdal 2018a, 2018b). Such an encounter, or explicit non-encounter, is often not interpreted as a space and is sometimes referred to as a 'nonspace' to illustrate this. Borderlands or border spaces may also be such nonspaces, as the encounters there are rarely the main object of interest. Furthermore, such nonspaces may be counterspaces, in that they, as in Michel Foucault's (1984) notion of heterotopia, may be different from the dominant spaces, and through their very differences thus direct criticism towards society, threatening the general discourse and challenging the ethical discourse. They are also rich and complex social spaces. Thus, the border situation also pushes refugees and migrants to 'reshape their lives in order to ... give them a new form in a new place. [Creating a] complex and multifaceted flow of migrants who actively resist the restrictions imposed on them' (Katz 2017: 13) by biopolitical ordering and border sovereignty.

The premise here is that there are ways of discovering the calling, and that we meet in the calling as equal bodies with pathos, provided that it is something we are affected by (Waldenfels 2011: 27), provoking the sense of something 'done to us' (Waldenfels 2007: 74). Who calls and who responds is not something decided beforehand, it is unclear and open, and so are the premises of the spaces themselves.

\section{The Arctic route ${ }^{2}$}

In 2015, around 1.3 million people crossed the borders of Europe (Pew Research Center

2 The following account builds on news articles from local, national and international broadcasters in 2015 and 2016, non-academic and academic publications, as well as the informants of this project. I have included the details necessary to contextualize the chapter. The political, departmental and legal version of the events and the local experience of them may differ. 
2016). They were refugees and migrants coming from a wide range of nations, finding any possible route into a European nation. Norway has a 196-kilometre border with Russia. Two thirds of it follows the courses of rivers. 230 Norwegian soldiers guard the Norwegian side, while the same number of Russians soldiers guard their side. 396 border posts mark the border: yellow and black on the Norwegian side, red and green on the Russian. Russia additionally has a fenced-in militarized security zone for several kilometres into the country. Only one road crosses the border, and consequently, the entire border has one border station, called Storskog. It is illegal to make the crossing on foot, but a bicycle is considered a vehicle.

At the beginning of the twenty-first century, an average of five asylum seekers crossed this border annually. ${ }^{3}$ In 2015 , 5,465 asylum seekers found their way along this route into Norway on bicycles, most granted once-through visas in Russia. Already in March 2015, a few asylum seekers crossed this border. In August, a hundred people crossed, and new records were set every day. By October 50 to 60 people crossed every day. According to the Norwegian law, asylum applications can be processed at the border, or inside the territory. As it was impossible to differentiate between those seeking asylum and others, as well as handling the sheer number of people arriving, the border authorities simply decided to let every third-nation citizen enter.

The local police, politicians and population mobilized. The transit reception centre, the nearby asylum seeker receptions centres, as well as all the hotels in the area were full. The local politicians as well as the local news station reported on the situation but were unable to catch the attention of the capital. The international media, however, were attentive, and once they started broadcasting from Storskog, the Norwegian media and government realized that this was an international event.

Furthermore, it became a national and international political issue. The refugees heading to Norway were piling up in the two Russian cities closest to Storskog, Nikel and Zapoljarnyj, creating a difficult situation among the politicians, locals and amongst the migrants themselves. Russian border authorities and Norwegian police agreed on a maximum of 200 border crossings per day.

Once the Norwegian government realized the severity of the situation, they mobilized to find means to control and eventually stop the increasing flow of migrants using the Arctic route into Norway. To stop the stream of asylum seekers the law had to be changed. What may be the fastest legislative amendment in Norway was performed in 10 days. The state secretary himself travelled to the border to oversee the end of allowing asylum seekers in. The police and local agencies were critical, as the area could not accommodate the numbers of people who had already arrived, as well as the fact that it was now late November and the climate conditions were endangering the situation. The state secretary and government were unaffected and additionally increased the offensive to deport the migrants. The lack of clear agreements with Russia, led to migrants being sent back and forth across the border zone several times. The government argued stolidly by law, pressurising the authorities on site. The asylum seekers were not accepted by the Russian government, which had been provoked by the Norwegian government's attempts to return people. The result was that with 328 
asylum seekers having been returned at the border, Russia ceased cooperating and none of those deported from Norway could re-enter Russia.

Before the legislative amendment, three out of four Syrians who arrived through Storskog were granted residency; subsequently only one of 259 was granted residency. The amendment also opened the way to apprehending people who were likely to be denied asylum, which led to several asylum seekers exploring the options of church asylum.

\section{Hospitality as ethics}

The borderland is also a 'new' space of encounter between religions, and in a precarious space holding creative qualities, creating a 'new' space of theological research (cf. Machado et al. 2018). Hospitality is linked to space as 'to practice hospitality is to welcome others into what will become a shared space with the presence of another' (Reaves 2016: 39), and in the case of the narratives discussed here, this shared space was a borderland.

What is hospitality; what is its content? Academic and non-academic literature alike does not offer a single, universal definition.

...there are consequences to the fact that there is no single definition, mainly found in the variety of ways in which hospitality is discussed while lacking a cohesive sense of authority and practice in communities. Therefore, instead of looking for a definition of hospitality, it is more beneficial to explore the meaning of hospitality. (Reaves 2016: 37)

And, I would add, explore the spaces where, maybe, it is practised and lived. Can we even talk of hospitality without start- ing from the encounters between humans? Without embodied, lived, spatial encounters? Hospitality is conceptually linked to theology, and ultimately appears as an ethical demand in one form or another, 'ethics-as-hospitality' (Dikeç et al. 2009: 9). 'When it is the ethical challenge of the other that is central, and this is confronted in action, then a theologically relevant practice takes place' (Wyller 2008: 179). The calling is thus also essentially related to ethics. It is, according to Nahnfeldt (2016), a holistic view and life attitude. We are sent out into the everyday with an ethical request: we should take responsibility for other humans and meet their needs. This request challenges us to ask questions; who to listen to and what their needs really are (ibid.). By linking hospitality to the concept of calling, I introduce hospitality as something that may entail resistance from and for those involved.

When talking of hospitality, there is usually an idea of someone, often with little to give, coming to someone already there, who (can) offer shelter and bare necessities. There are guests and hosts, and often a general idea of temporality, in the sense that the guest is expected not to stay indefinitely. I introduce a sense of a hospitality that interchanges, that may entail resistance from and for those involved.

\section{The Arctic borderlands:}

\section{a 'heritage of resistance'}

The region has had national borders since 1826 when the frontier between Norway and Russia was first staked out. Subsequently the borders between Russia and Finland have been drawn, re-drawn and fought over many times. People have inhabited the area for more than 10,000 years. Until around 200 years ago, the population consisted mostly of Sami people who have been following reindeer migra- 
tion routes regardless and irrespective of these modern frontiers, and people on all sides are connected to each other through family bonds and friendships. Industry and international politics have been the decisive forces of change, exerting an influence on who has settled and formed the population. The borders have been implicated in refugees coming this way before; from times of war and enmity between Russia and Finland.

Throughout the Second World War people here also lived alongside strangers. Around 160,000 German soldiers were living in the area of Sør-Varanger during the war years, and many stayed in people's homes, often while the families were still living there - or many families stayed together in one house as the Germans had seized their homes. Additionally, as many as 65,000 Soviet war prisoners were in the many camps in the area - in a county of about 7,000 inhabitants. During the war locals themselves fled or were evacuated by force. The area was devastatingly bombed by the allies and torched by the Germans. ${ }^{4}$ Many children were sent to Sweden when the war ended, for nourishment and healing, after years of food deprivation and sickness. During the 1990 s there was a direct route from Kosovo ${ }^{5}$ to Sør-Varanger, as the region is a reception county. This historical and collective

4 Due to its geographical location the county of Sør-Varanger was of particular interest to all sides in WWII, and the area paid an enormous price. Kirkenes was one of Europe's most bombed cities (328 bombardments). In October 1944, Kirkenes was burned to the ground, leaving only 39 houses intact.

5 In news items and articles, there are some disagreements on the city of origin; I have found variously Skopje, Pristina, Sarajevo and Kosovo. memory in the area may be a kind of 'heritage of resistance' (Reaves 2016: 6), forming local hospitality practices.

\section{Borderland encounters}

If you can get airline tickets, or by other means reach Murmansk, you can get to Zapoljarnyj or Nikel, two cities with populations of 10,000-15,000, 30 and 50 kilometres from Storskog and the Norwegian border. The cities have clear boundaries, and between them and Storskog there is mostly wilderness with sparse vegetation, a rocky landscape with small, windswept Arctic birch trees that, as you get closer to Norway eventually give way to tall pines. There are no lights, no houses, no gas stations, no people. Only passing cars, lorries, and buses. This area is as far east as Istanbul, and once you cross into Norway, you jump over two time zones.

Thirteen kilometres from Storskog, on the other side of the border, in the county of Sør-Varanger is Kirkenes, a town with 3,500 inhabitants. In Kirkenes you feel the vicinity to, and presence of, other nations, with street signs in both Russian and Norwegian. Finland is only a forty-minute drive away, and Finnish influence is also detectible in the names of people and places. Sør-Varanger lies far away from the capital, the geopolitical centre of Norway.

As in most border areas the locals travel 'next door' to do their shopping. In Kirkenes people go to Russia and Finland to save some money. Many go to Russia once a week to fill up their cars' gas tanks, as the price of gas and diesel is considerably lower than in Norway. Many also go to Russia for a Friday beer or payday beer, again due to the lower price. They must be sure to remember the time difference, crossing the border before the Norwegian border control guards close for the night. Locals have a grenseboerbevis (local border 
traffic permit) and may cross the border without visas.

\section{Hospitality and the other}

There is a local claim that there is something called North Norwegian hospitality. I am interested in whether this exists, and does it have something to do with the border? Through media reporting from Storskog in 2015-16, it became clear that several local people were engaged in the crisis. Two people, Lars and Maria, were among those who acted when 'the refugees came' across Storskog.

Lars, a man in his late forties, is one of many locals who goes to Russia for cheap fuel. During the fall of 2015 he meets families wandering the desolate road between Nikel and Storskog; more and more people, and many small children, who are either walking or bicycling. These people are not dressed for the harsh climate here. He, a man who used to be an adamant opponent of immigration, an 'unknowing sceptic' as he calls himself, is moved to action. 'Those bicycling from Nikel - it is $30 \mathrm{~km}$ - started to get very cold. The locals drove like crazy. They were so exhausted; there were small children. I started driving over with clothes and other things. It is illegal to take people in the car, because of the border zone. It did something to me; people shouldn't be in such a situation.' 6

The refugee crisis completely altered the course of Lars's life, 'My life has turned around 180 degrees, completely upsidedown, in the last three years.' After the situation at Storskog and Kirkenes had calmed down, after the border was closed, Lars had only begun his engagement with refugees.

6 The quotes from the interviews have been translated to as closely as possible reflect the sentiments expressed in Norwegian.
It was impossible for him to not continue taking action, and he had, by the time of the interview, been to Greece three times, to a camp in the north of that country. Lars tells me about the things he has learned, how enriched his life has become; all that he has been given through his experiences with the refugees.

At the same time that Lars is going through this, Maria, a nurse with two grown children, is watching the news. Families are walking or bicycling in the nothingness on the way to Storskog. She sees small children and exhausted parents - almost invisible bodies in the darkest darkness in this bare landscape. She sees people in danger and is moved to action. 'Many people were freezing. They were not dressed for the Arctic. They had never worn wool as a base layer, or down jackets and those kinds of clothes. That is how I got involved, watching the news and thinking "Oh my god, they are freezing to death, these poor refugees!", so I started collecting winter clothes here in Kirkenes.' Maria starts driving over to Nikel, to the hotel there that is the last pitstop before the border. She brings clothes and reflective wear.

In these explorations of hospitality, I include the perspective of the lived, common space, and the bodies participating in them. When discussing the concept of hospitality, it may be fruitful to use spatial concepts in order to search for, find, and understand such hospitality, as it is enacted and lived among humans. Following the notion of nonspace, encounters may provide moments of safety and protection. This is elegantly illustrated by Elie Wiesel, whose following quote regarding Jewish tradition, sums up how I understand (non)space, body and hospitality to be connected: '... when we speak of sanctuary, it refers to human beings. Sanctuary, then, is not a place. Sanctuary is a human 


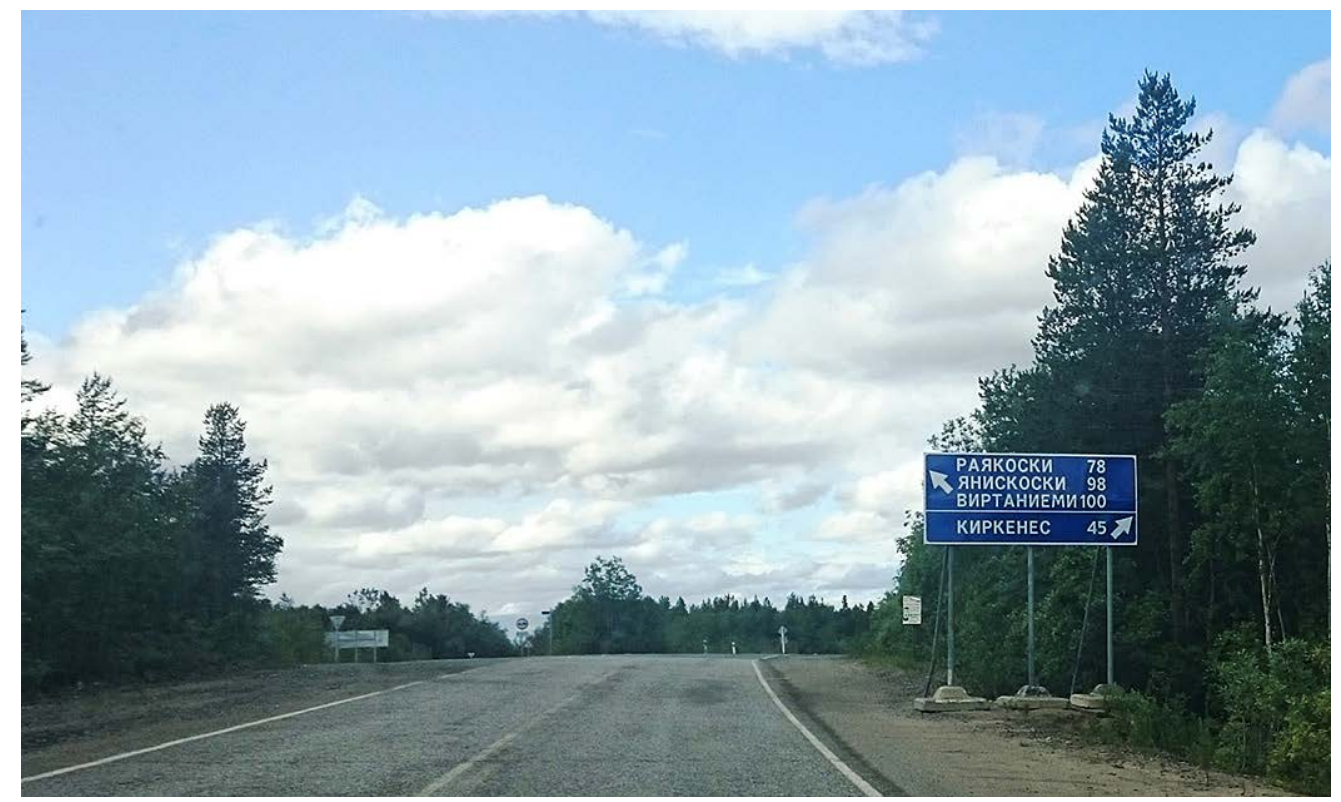

Roadsign on the road from Zapoljarnyj. To the right is north to Kirkenes, to the left is southeast towards the Finnish border. Photo: Kaia Rønsdal, June 2017.

being. Any human being is a sanctuary' (Wiesel 1984-5:387).

Borders shift; 'the border that used to keep ethnic "Others" very far away has come close to us, to the centre of our cities and national governance' (Agier 2016: 25). Borders are understood as 'multidimensional but ambiguous sites that have symbolic, religious, moral and political dimensions' (Machado et al. 2018: 7).

When starting from the notion of borderlands as 'places of recognition and exchange between individuals' (Agier 2016: 16), what does the concept of hospitality entail when based on encounters in real, lived borderland space? This is developed by exploring how border encounters are lived spatially (Lefebvre 2007). This direction would mainly follow the phenomenological discussion on others and borders, the guest/host, and other binaries. Although Sør-Varanger is a small county, geographically far from national government, yet living everyday life with and on the nation's border, the crisis led to the border shifting, making this place the centre. It was the borderland, an ambiguous site and object of national governance.

\section{The other at the border}

Lars and Maria and a few other people soon became the key civil agents for the refugee network in Kirkenes.

We drove over many times with warm sweaters, coats, shoes, beanies and reflective wear. Things that were donated, and from our own closets. A lot of people donated. It almost became an obsession to drive over, and in the end we almost went daily. We didn't know how many were coming. In the end almost 200 people crossed the border daily. Maria and I drove together many times, but also I went over to fill up alone. But it was obviously not only us, there were many others. We were not outstanding, but we might have been the most visible because we were so much on social 
media and urged people to drive over. We got so much scolding, but there are worse things to be scolded for, for fuck's sake.

I have been to Kirkenes many times. I have been across the borders to Russia and Finland. I have been to the hotels in Zapoljarnyj and Nikel where the refugees stayed (in all the rooms, hallways, meeting rooms) before they started their walk towards Norway. I have driven on the road to Storskog. I have seen and felt the desolation and distance. I have felt the Arctic winter on and in my body, on my nose and hands, felt how the lungs shrink when you inhale the cold air. I have read about Lars and Maria in news items from all over the world; two ordinary people who were moved to action when the refugees came to Norway.

Maria and Lars got engaged in the political crisis that suddenly had its epicentre in Kirkenes, at Storskog and at the transit/deportation centre. They helped people on the Norwegian side and on the Russian side; they talked to everyone who listened:

It was hectic, and it was completely absorbing for a period of time. One thing was the practical, and after we were arrested it exploded in the media, and I don't know how many 10os of interviews we did. It was intense. But we were focused on getting it out there; the whole world had to know how hellishly we were treating these refugees, Norway, one of the richest countries in the world, Norway the nation of peace, right?

We talked about so-called North Norwegian hospitality, and Kirkenes as a historic place of reception. They told me of doors that are always open in Kirkenes; people will enter each other's homes and get a cup of coffee, 'There is always coffee', even when there is no one home. Maria thinks this has to do with the war. As the Germans occupied people's homes for their own use, families would move into other families' homes. Maria's grandparents had told her how they lived several families together in one home, and that this was part of people's narrative, thus shaping them as being maybe more welcoming and open. Lars said: 'Borders and border experience and the border area, it's significant. It comes in our mother's milk, history, parents and grandparents. In the Balkans in the 9os, people were received with open arms.

We have talked about what they, Lars and Maria, did; what drove them, what they have done subsequently, and how the experience has shaped them, as well as many, many other things connected to what took place back then. Both were arrested when the situation in Kirkenes was at its most critical and they were charged with helping people escape the police (and deportation) into church asylum in the church of Kirkenes. She paid her fine. He spent three years being acquitted. Both state that their lives will never be as before the refugees came. Both were threatened, scolded, and Lars even received death threats. But they will never look back. Maria said: 'My life is before and after the refugees came ... Getting involved and how much you receive in return... fantastic people! So, it is obvious that it changed me in many ways.'

Both said that their lives would never be the same as before the refugees came. When we reflected on hospitality, they both mentioned the refugees as most hospitable. That they, Lars and Maria, had never received so much hospitality as when the refugees came. Maria said: 
They have it in their culture, and we have so much to learn. They are super hospitable. ... So they are used to it, we didn't teach them up here ... And they think we do not visit enough. After some days they call and say: 'it's been too long, Maria, what are you doing?' In that way they are amazing.

When talking about this with Lars, he used examples both from Kirkenes and from his experiences in the Greek camps:

It was quite interesting. I am there to help, they are where they are, in their [temporary] homes. And it is true, we are guests. To be fellow humans, to help them in a terrible situation. They have no other place in the entire world than right there, it is their home, we are their guests, it's as simple as that.

And later, in continuation, he said: 'We were invited into the tents, every day, to food, tea coffee, friendships, it was unbelievable!' (my emphasis).

\section{An ethical demand}

How could we interpret the hospitality Lars and Maria talk about experiencing at Storskog? To answer this, I will explore these narratives or statements on experienced hospitality using phenomenological concepts. The employed perspectives explicitly emphasise the role of practical experience. Furthermore, the geographical, political and historical context setting the stage for these narratives is significant, as the embodied memories and presence of the people who play a part in it are shaped in this particular context, and they produced and continue to produce this particular space.

Hospitality has a clear ethical dimension, and by linking it to a specifically Lutheran tradition, I will explore what kind of hospitality this may be.

The Danish philosopher and theologian Knud E. Løgstrup's most famous work is The Ethical Demand (first published in 1956). He stated that you can never engage with another human without holding pieces of his life in your hand, and the demand is that we care for that life. In the Nordic countries during the last half of the twentieth century, theological thinkers such as Løgstrup developed a theology and philosophy that shaped his work on ethics. One central dimension here is that ethics are developed in the encounters between humans. Although a theologian himself, Løgstrup rejected making the question of compassion and care a religious one. Rather, he made them a universal challenge to everybody, in a reciprocal interdependence regardless of faith or creed (Løgstrup 2000; Christoffersen 1999). This ethical demand is thus not a religious concept, but rather a universal concept that every human being is called by the other to heed this other life and take care of and protect it. In my interpretation, this concerns both biological life, as well as the socio-ethical responsibility of living with respect for other lives. This should mean that when refugees come to our doors, they are the life held in our hand to care for, to show hospitality.

Lars and Maria both stated that hospitality was something that came with the refugees. If that is the case, it challenges this notion. If hospitality comes with the other, the concept of calling from traditional thinkers such as Løgstrup is contested. In order to discuss this and explore other possible interpretations I will start by introducing some perspectives influenced by the tradition of Løgstrup, as these will also play a part in my explorations. I will emphasise the philosophical and universally ethical understanding in the exploration of hospitality. 
Scandinavian creation theology, to which Løgstrup was a central contributor, is one starting point. Central to Scandinavian creation theology is the notion that life has been created and given to us (Løgstrup 2000: 41); we did not create it ourselves. Some believe it is created by a deity, and some believe that it comes into existence by other means. Regardless of belief, we do not decide our own lives and we do not create it. Life is continuously created, in the here and now (Wingren 1995 [1974]: 35f.; 39f.). This shapes our world and our relationships and encounters with other people (Løgstrup 2000: 39). It is central to the Lutheran view of man to bear responsibility for one's fellow man. The fact that to be human is to be called is constitutional of what it is to be human (Nahnfeldt 2016: 17). There are, according to Løgstrup, phenomena and aspects of human life that are not subject to our power, that emanate from and belong to life itself (Løgstrup 2000: 30, 35, 38f.). He calls these the sovereign expressions of life, and they are phenomena such as compassion, trust, and openness of speech. His point is that these are the phenomena with which lives encounter lives, and these encounters are where ethics develop. Norms only come into play in moral action when these spontaneous responses fail (2000, 1972). As we are created (by God), life is expressed as care for, and reception of, the other. The responsibility is founded in an idea about humans' co-creating missions and adds a sacred dimension and ethical value to interpersonal encounters and practices (Nahnfeldt 2016: 17). In Luther's perspective the calling belongs to creation and the human being's task to be a co-creator; that this takes place through everyday activities, and that places her in relation with her fellow human beings (ibid. p. 73). That the world and other humans are not our creations is decisive in how we think about, and act towards, them. Feminist theologian Letty Russel claims that

[Christian] theologians who are committed to practicing God's hospitality and justice are called to develop a critical way of doing theology that makes sense to those who are marginalized and excluded (by neoconservative rhetoric and actions), [and to] assist in God's intention for the mending of creation ... (Russell 1996: 477-8).

The Other has always been an important figure and phenomenon for theology; for example as the other who lives in poverty, who is tired and in need, and the 'radical Other, who is God hidden behind ...' (Boff 2011:48), the larvae dei (God's mask), 'the idea of God acting in the ordinary life shared by all in, between, and behind the face of other human persons' (Gregersen et al. 2017: 15).

In phenomenology the fact that we share a (created) life, reality, and world makes us part of the same lifeworld (with divine presence): 'A human is inherently related to others, to nature, culture and society' (Wyller 2010: 190). Furthermore, we 'share the same planet, and therefore unavoidably live at the expense of other life-forms, and repeatedly do so at the expense of others' (Gregersen et al. 2016: 21) - including the Other, who is very different from us.

Following these lines of thought we see a (theological) thinking that is 'particularly interested in thinking of reality as a radically open concept, which leaves space to think otherness and changeability for the world. Such extensions into discourse are open for discussion, not holy laws to be either condoned or condemned' (Heimbrock and Meyer 2010: 199). It is a normative, philosophical, life-interpreting approach to God, life, humans, and the world, developed 
within Protestantism and usually referred to as systematic theology. This theological approach is tightly interwoven with Scandinavian creation theology.

Scandinavian creation theology stands and falls with the claim that there are shared aspects of human life that offer room for open-minded discussions of how to live the human condition alongside people of other faiths, and with people of no professed faith at all. Scandinavian creation theology leaves ample room for common sense and common commitments, even where worldviews differ or even drift apart. Everyday life constitutes a third realm between a purely political realm, and a purely religious domain. (Uggla et al. 2017: 8)

For this context the important dimension to this particular theological tradition is the interpretation of the world as 'already God's creation, a reality which should be cared for and enjoyed for its own sake, by believers and non-believers alike' (Uggla et al. 2017: 11). It is a theology where our fellow human, also she who is radically other, is at the centre and humanity is one of the goals of creation.

The other central and explicitly theological distinction in this tradition is the profession of a divine presence also outside religious or sacred spaces. 'Vocation points to the present, to the present day, to this world' (Wingren 2004 [1957]: 28) to the everyday and everyday spaces. This is also true in the everyday lives of people who do not necessarily think of themselves as being religious. This gives a sacredness to everyday life and to everyday spaces that are open to theological interpretations of aspects and locations of life traditionally not thought of as sacred, those not considered significant. This could be the drinkers on the park bench, the Roma living under a highway bridge, or the beggar and the passers-by, smiling, or ignoring him. In these non-spaces it is not obvious where the calling may appear (Rønsdal 2018a, 2018b). The humans producing these spaces, who may be fundamentally other to myself, are also a part of this shared condition of living in a world that is continuously being created. This implies that calling, according to Lutheran interpretation, is about people's inter-human relations, not people's Godrelation (Nahnfeldt 2016: 111). The ethical demand where you can never encounter another human without caring for the pieces of this life that is placed in your hand is based on this tradition.

Even though this is fundamental thinking in this theological and ethical tradition, it does not quite fit the narrative of Lars and Maria, and their experience of receiving hospitality from the refugees. In their encounters with the refugees there is something more than holding the other's life in one's hand. This notion does not completely resonate with the experiences in the narratives. It seems that their narrative cannot be safeguarded by Løgstrup's notion of holding pieces of the other's life in one's hands.

\section{Embodied hospitality}

What is the significance of the fact that Lars and Maria had never encountered such hospitality as when the refugees came? They were the ones who opened their arms, homes and lives. They drove to Russia with food, water, and reflective wear. They partook in language classes, taught people how to dress, arranged childcare, and so much more. They risked fines and prison to help refugees from deportation. They worked around the clock for months, were called at all hours by people who needed help or assistance. Still, their spontaneous reply 
when asked about hospitality is that it is something they received. No words about Northern Norwegian hospitality, a heritage of resistance, or how people in the borderlands always have helped each other, or experiences of receiving. In their own encounters with the refugees, it was only: we have never experienced such hospitality as when the refugees came.

Lars said: 'And it is true, we are guests. To be fellow humans, to help them in a terrible situation. They have no other place in the entire world than right there, it is their home, we are their guests, it's as simple as that.' My concern is that it challenges perceptions and conceptions about hospitality, and that it shows something I will ultimately call fluid hospitality. It shows us that the conceptual roles of guest and host are not finalised. On the contrary, it is quite unclear what they entail. From the outside the roles seem clear - someone came from the outside, others received. On the inside, where people encounter and have real and lived experiences, it is pending.

The dichotomy, or binary, of guest and host is interchangeable and dynamic. One may think that in this context it is only 'we' who have the freedom and liberty to move in and out of the roles of guest and host, while people who are fleeing are locked in their roles, as they do not have the choices and freedoms we have. However, this is limiting both the guests and hosts to the binaries, where a guest is someone who is a victim, a villain, a refugee, unfree. Regardless of the labels we place on each other, particularly from the macro perspective, none of us are static; our roles are negotiated and interchanged continuously; 'we were invited ... to friendships'. In the narrative, there are few expressions of expectation or demand; it is at times descriptions of joining the refugees in everyday life. Philosopher Rosalyn Diprose writes of a corporeal generosity, that it is not one virtue among others but the primordial condition of personal, interpersonal, and communal existence' (Diprose 2002: 5). I interpret this corporeal generosity to lie close to the hospitality emerging in the narratives.

The statements on hospitality - that it was something experienced by those one may think of as hosts, intrigued me, and may just point out something. The events forming the background of the narrative were located so close to the border where someone who was not supposed to come came. They may have had nothing, and that is apparently the reason they had nothing to give, and no one on either side had the time to make up an opinion - certain circumstances fell together in a way that made certain encounters possible. Corporeal generosity is an openness to others that not only precedes and establishes communal relations but constitutes the self as open to otherness' (Diprose 2002: 4). At the border, the circumstances were such that there was little time for deliberation.

Maybe this can be tied to the idea of the border: 'we may well be in that space (or time) of in-between "no longer" and "not yet" that provides opportunities for thinking and acting differently. If "we, the people" is no longer convincing or effective, "we the connected" has not yet become so' (Isin 2012: 165-6). This statement points to creative potential, human encounter and connectedness, in-betweenness and rupture, all opening up for change, counteraction and thus resistance. 'The future - the notyet, not-here - is given to us as that which comes to us from the other, from what is absolutely surprising, new, incalculable untimely' (Dufourmantelle 2013: 19).

In modern society, there is little time or sympathy for detours and delays - hospitality, generosity and calling are in themselves counter to this. It is the detours and delays 
that disturb, break, and open up potential to the creative, to resistance. A space is constantly in motion, always different, always being moved forward, being produced the world is moved forward by contrasts, contradictions, and tensions (Lefebvre 2007: 42).

Furthermore, nonspaces or heterotopias, and borders, are associated with possibilities, something new and maybe surprising; an in-between. 'The location of the in-between comes to existence in the exact moment when the boundary line is crossed, overcome and experienced' (Luz 2006: 143). Diprose, building on Nietzsche, writes of corporeal generosity that it is a writing blood that says this body carries a trace of the other, so this body and its cultural expression are not finished, and neither you nor I have the final word' (Diprose 2002: 195).

Hospitality, then, may be an embodied, pre-reflexive, enacted and lived generosity towards the other human, entailing an openness and willingness to let the other affect, disrupt, setting my life in motion, touching 'me rather than finishing me or others off' (Diprose 2002: 195).

Hospitality describes a figure, a space that allows a gesture of invitation to take place. That is, I believe the space of thinking itself. To think is to invite, to offer a shelter to the other within ourselves, the other as the possibility to be(come) ourselves. As the experience of an encounter and a recognition, ... It holds together, as separated, the profane and the sacred. (Dufourmantelle 2013: 13-14)

In these human encounters, bodies interact in ways that let us interpret them as encounters of hospitality unlike anything experienced before. When the calling, and thus hospitality, is turned upside down it becomes interchangeable. The subjectivity of hospitality is removed from an unambiguous 'I am called' to the others having the role of subject. Becoming the subject is resistance. It is an absolutely radical transformation of the calling, and an extension of hospitality.

\section{Concluding remarks}

In the recounted events in Kirkenes, the people in the narratives were involved in geopolitical power spaces. However, there is at the same time another production of space going on. The embodied hospitality they experience in the lived space points to counterspaces, to resistance. This lived space has certain qualities that break with representations of the space and thus create another kind of interaction within - and that is where the calling and thus hospitality is uncovered and can be discussed. That is why spatial interpretation is important for the calling for embodied hospitality and resistance.

The individuals who encountered each other in those months during 2015 and 2016 were all bodies who reached out to each other and responded to each other's embodied spatial callings, thus also exchanging hospitality. Embodied hospitality has nothing to do with what you have to give. Rather, it is hospitality which is immaterial, transcendent and sensitive. The human who encounters is prepared to create anew from the experience, being curious about those encountered (Nahnfeldt 2016: 187-8). In this embodied hospitality the encountering bodies surrender, or even entrust themselves to each other, transcending the usual conceptions of (the boundaries of) hospitality.

The spatial interpretations of the border and the displaced reveal the actual spatial locations of everyday life and social life. As 
lives that are usually lived 'off-site' in reference to either the academy or church it may still be the most significant locus of hospitable practice and even the locus where the practice should be founded.

Furthermore, the dogmatic loci pointed out by the theologian Kathryn Tanner (2004) in her initial definition of loci theologici must be reconfigured spatially. She herself suggests that the new dogmas in such a theology should be

... mobility and rootedness in place, dislocation and belonging, connection and disjunction, occlusion and display, division and incorporation, exclusion and inclusion - new, redemptive orderings of all these spatial forms so as to rework the old in life-enhancing and spiritually fulfilling ways. (Tanner 2004: xiii)

In my view, if one is to explore the concept of theological spaces it is crucial to maintain that the lived-space heterotopia is a concrete and present space, not an 'almost-space'. These spaces, the borders, are real spaces, the body is located somewhere, always, in the concrete productions of space. We are always physically placed bodies in lived space, participating in its everyday production. In Sør-Varanger they may have been producing spaces of a shared and interchanging embodied hospitality.

The displaced and the 'placed' bodies are all producing hospitable space, and that space existed from the moment of encounter. It is not spaces hopefully appearing in the future. The spaces are already here, and we are already in the concrete, lived spaces of everyday life. It is no longer a source or geographical locus, it is not somewhere we have to look for or visualise in the yet to be; the lived locus is already here.
Dr Kaia S. Rønsdal is currently a post-doctoral fellow at the Faculty of Theology, University of Oslo, and member of the research group 'NORDHOST: Nordic Hospitalities in a Context of Migration and Refugee Crisis'. Her discipline is the field of professional ethics and Christian social practice, and her main research interests are on marginality, borders, and peripheries include spatial theory, urbanity, phenomenology and theological ethics. She is currently working on a project on interreligious dialogue and social cohesion in relation to migrant and refugee reception in Europe, which also includes further explorations on the concept of hospitality. The lived practices in civil society are her primary interest.

\section{Bibliography}

Agamben, Giorgio. 1998. Homo Sacer: Sovereign Power and Bare Life (Stanford University Press).

Agier, Michel. 2016. 'Epistemological decentring: at the root of a contemporary and situational anthropology', Anthropological Theory, 16(1): 22-47.

Boff, Leonardo. 2011. Virtues: For Another Possible World (Eugene, OR: Cascade Books).

Chattopadhyay, Sutapa. 2019. 'Borders re/make bodies and bodies are made to make borders: storying migrant trajectories', Acme: An International Journal for Critical Geography, 18(1): 149-72.

Christoffersen, Svein Aage. 1999. Etikk, eksistens og modernitet. Innføring $i$ Løgstrups tenkning (Otta: Tano Aschehoug).

Dikeç, Mustafa, Nigel Clark, and Clive Barnett. 2009. 'Extending hospitality: giving space, taking time', Paragraph, 32(1): 1-14.

Diprose, Rosalyn. 2002. Corporeal Generosity: On Giving with Nietzsche, Merleau-Ponty, and Lévinas (Albany: State University of New York Press).

Duformantelle, Anne. 2013. 'Hospitality: under compassion and violence, in The Conditions of Hospitality: Ethics, Politics, and Aesthetics on the Threshold of the Possible, ed. Thomas Claviez (New York: Fordham University Press), 13-23. 
Foucault, Michel. 1984. 'Of other spaces (1967): heterotopias', in Architecture/Mouvement/ Continuité, Oct. 1984: 1-9.

Gregersen, Niels Henrik, Bengt Kristensson Uggla, and Trygve E. Wyller (eds.). 2017. Reformation Theology for a Post-Secular Age: Løgstrup, Prenter, Wingren, and the Future of Scandinavian Creation Theology, Research in Contemporary Religion (Göttingen: Vandenhoeck \& Ruprecht GmbH \& Co).

Heimbrock, Hans-Günther, and Peter Meyer. 2010. 'Theology as model for perceiving the other', in Perceiving the Other: Case Studies and Theories of Respectful Action, eds. Trygve Wyller and Hans-Günther Heimbrock, Research in Contemporary Religion (Göttingen: Vandenhoeck \& Ruprecht $\mathrm{GmbH} \& \mathrm{Co}), 192-201$.

Houtum, Henk van, and Freerk Boedeltje. 2009. 'Europe's shame: death at the borders of the EU', Antipode, 41(2): 226-30.

Isin, Engin. 2012. Citizens Without Frontiers (London: Bloomsbury Academic).

Katz, Irit. 2017. 'Between bare life and everyday life: spatializing Europe's migrant camps, Arhitecture_MPS, 12(2), 2.10.2017: 1-20, doi: <10.14324/111.444. amps.2017v12i2.001>.

Lefebvre, Henri. 2003 (1970). The Urban Revolution, trans. R. Bononno (Minneapolis: University of Minnesota Press).

- - 2007 (1974). The Production of Space, trans. Donald Nicholson-Smith (Malden, MA: Wiley-Blackwell).

- - 2008 (1961). Critique of Everyday Life, vol. 2. Foundations for a Sociology of the Everyday, trans. John Moore (Malden, MA: Verso Books).

Lid, Inger Marie, and Trygve E. Wyller (eds.). Forthcoming. Motstand og Motmakt (Oslo: Cappelen Damm Akademisk).

Løgstrup, Knud E. 1972. Norm og spontaneitet. Etik og politik mellem teknokrati og dilettantokrati (Copenhagen: Gyldendal).

- -2000 (1956). Den etiske fordring (The Ethical Demand) (Trondheim: J. W. Cappelens Forlag).

Luz, Ana M. 2006. 'Places in-between: the transit(ional) locations of nomadic narratives', PLACE and LOCATION: Studies in Environmental Aesthetics and Semiotics, 5: 143-65.
Machado, Daisy L., Brian S. Turner, and Trygve E. Wyller (eds.). 2018. Borderland Religion: Ambiguous Practices of Difference, Hope and Beyond (London: Routledge).

Nahnfeldt, Cecilia. 2016. Luthersk kallelse. Handlingskraft och barmhärtighet (Stockholm: Verbum).

Pew Research Center. 2016. 'Number of refugees to Europe surges to record 1.3 million in 2015, Pew Research Center, 2.8.2016, <https://www.pewresearch.org/ global/2016/08/02/number-of-refugeesto-europe-surges-to-record-1-3-millionin-2015/> (accessed 24.8.2020).

Reaves, Jayme R. 2016. Safeguarding the Stranger: An Abrahamic Theology and Ethic of Protective Hospitality (Eugene, OR: Pickwick Publications).

Rønsdal, Kaia S., 2018a. Calling Bodies in Lived Space: Spatial Explorations on the Concept of Calling in a Public Urban Space, Research in Contemporary Religion (Göttingen: Vandenhoeck \& Ruprecht GmbH \& Co).

- 2018b. 'Hverdagsmarginalisering og bytilhørighet', in Rom og etikk. Fortellinger om ambivalens, eds. Inger Marie Lid and Trygve Wyller (Oslo: Cappelen Damm Akademisk), 55-72, doi: <https://doi. org/10.23865/noasp.18>.

Russell, Letty M. 1996. 'Practicing hospitality in a time of backlash', Theology Today, 52(4): 476-84.

Simonsen, Kirsten. 2010. 'Rumlig praksis. Konstitution af rum mellem materialitet og repræsentation', Slagmark, 57: 35-58.

Tanner, Kathryn (ed.). 2004. Spirit in the Cities: Searching for Soul in the Urban Landscape (Minneapolis: Augsburg Fortress Publishers).

Uggla, Bengt Kristensson, Trygve E. Wyller, and Niels Henrik Gregersen, 2017. 'Preface', in Reformation Theology for a Post-Secular Age: Løgstrup, Prenter, Wingren, and the Future of Scandinavian Creation Theology, eds. Niels Henrik Gregersen, Bengt Kristensson Uggla and Trygve E. Wyller, Research in Contemporary Religion (Göttingen: Vandenhoeck \& Ruprecht GmbH \& Co), 7-9.

Waldenfels, Bernhard. 2007. The Question on the Other (Albany: State University of New York Press).

-_2011. Phenomenology of the Alien: Basic 
Concepts (Evanston, IL: Northwestern University Press).

Wiesel, Elie, 1984-5. 'The refuge', CrossCurrents, 34(4): 385-90.

Wingren, Gustaf. 1995 (1974). Credo. Den kristna tros- och livsåskådningen (Skellefteå: Artos).

--2004 (1957). Luther on Vocation, trans. Carl C. Rasmussen (Eugene OR: Wilf \& Stock Publishers).

Wyller, Trygve. 2008. 'Compassion as an interruption of the power of inscription: a contribution to diaconal studies', in Lived Religion: Conceptual, Empirical and Practical-Theological Approaches. Essays in Honor of Hans-Günther Heimbrock, eds. Heinz Streib, Astrid Dinter and Kerstin Söderblom (Leiden: Brill Academic Pub.) 171-82.

- 2010. 'Religion and professional ethics in a post-secular society', in Perceiving the Other: Case Studies and Theories of Respectful Action, eds. Trygve Wyller and Hans-Günther Heimbrock, Research in Contemporary Religion (Göttingen: Vandenhoeck \& Ruprecht GmbH \& Co), 188-91. 